\title{
Yerel, yabani ve ticari kabakgillerde külleme hastalık etmenlerinin belirlenmesi, tanılanması ve dayanıklılığın araştırılması
}

\section{Determination and identification of powdery mildews on domestic, wild and commercial cucurbits}

\author{
Mustafa YÜCESON (i), Mümin İbrahim TEK (i), Özer ÇALIŞ (i) \\ Akdeniz Üniversitesi, Ziraat Fakültesi, Bitki Koruma Bölümü, Kampüs, 07059, Konyaaltı/Antalya \\ Sorumlu yazar (Corresponding author): Ö. Çalış, e-posta (e-mail): ozercalis@akdeniz.edu.tr \\ Yazar(lar)e-posta (Author e-mail): yucesonmustafa@gmail.com, 3mibrahimtek1@gmail.com
}

\section{MAKALE BİLGİSİ}

Alınıs tarihi 30 Mart 2020

Düzeltilme tarihi 08 Haziran 2020

Kabul tarihi 10 Haziran 2020

\section{Anahtar Kelimeler:}

Kabakgiller

Külleme hastalıkları

Podosphaera xanthii

Golovinomyces cichoracearum

Dayanıklilik

\begin{abstract}
$\ddot{O} \mathbf{Z}$
Kabakgiller Türkiye'de ve dünyada yoğun üretimi yapılan bir sebze grubudur. Külleme hastalıkları, kabakgil üretiminde ekonomik kayıplara neden olan hastalıkların başında gelmektedir. Günümüzde kabakgil külleme etmenleri; Podosphaera xanthii ve Golovinomyces cichoracearum türlerine karşı dayanıklı çeşitler konusunda yapılmış çalışmalar bulunmamaktadır. Bu çalışmanın amacı, Batı Akdeniz ile Doğu Akdeniz arasında yetișen yerel, yabani ve ticari su kabağı, acur, kavun, karpuz, hıyar, sakız kabağı, bal kabağı gibi çeşitli kabakgillerin genetik dayanıklılığını ortaya koymaktır. Çalışmada kabakgillerde verim kaybına neden olan, külleme hastalık etmenleri Podosphaera xanthii ve Golovinomyces cichoracearum türleri hassas hıyar çeşidi (Baccara) üzerinde kültüre alınmıştır. Kültüre alınan külleme etmeni üzerinde yapılan morfolojik, mikroskobik ve moleküler çalışmalar sonucunda patojen Podosphaera xanthii olarak tanımlanmıştır. Hastalık etmeni $P$. xanthi ile inokule edilen toplam 34 yerel, yabani ve ticari kabakgil çeşidi inokulasyondan sonraki ilk 3 gün boyunca mikroskopta trypan blue, diamino benzidine ve 3,3'-dihexyloxacarbocynin iodide (DiOC6) boyama yöntemleriyle incelenmiştir. Sonraki 7., 14. ve 21. günlerde bitkiler üzerindeki hastalık gelișimleri skorlanarak dayanıklı ve hassas kabakgiller bulunmuștur. Yapılan patojeniste testleri sonucunda VT18, Meltem F1, Poyraz F1 ve 348 ticari hiyar çeşitleri ile Adana kabak, Kaledran hıyar 1 ve Kaledran hıyar 2 yerel çeşitleri en dayanıklı kabakgiller olarak bulunmuştur. Çalışmada Kaledran kavun 2 yerel çeşidi $P$. xanthii'ye karşı en hassas bitki olarak belirlenmiştir. Çalışmalarda, külleme etmeni $P$. xanthii'ye karşı dayanıklı olarak bulunan yerel, yabani ve ticari genotipler gelecekteki islah çalışmaları için dayanıklılık kaynağı olarak kullanılabilecektir.
\end{abstract}

\section{ARTICLE INFO}

Received 30 March 2020

Received in revised form 08 June 2020 Accepted 10 June 2020

\section{Keywords:}

Cucurbits

Powdery mildew diseases

Podosphaera xanthii

Golovinomyces cichoracearum

Resistance

\begin{abstract}
Cucurbits are crucial vegetable groups significantly produce in Turkey and world-wide Powdery mildew (PM) pathogens cause economic losses in cucurbits production areas. There are not studies on resistant cucurbit varieties against to PM disease caused byPodosphaera xanthii and Golovinomyces cichoracearum. The aim of this study is to identify genetically resistant plants from landraces, wild and commercial cucurbits such as pumpkin, melon, watermelon, cucumber collected between West and East Mediterranean regions of Turkey. The PM agents were maintained on susceptible cucumber variety, Baccara. The maintained PM pathogen is identified as Podosphaera xanthii in microscopic, morphological and molecular studies. A total of 34 local, wild and commercial cucurbit species were inoculated with $P$. xanthi. The inoculated cucurbit plants were examined by trypan blue, diamino benzidine and 3,3'-dihexyloxacarbocynin iodide (DiOC6) staining methods during first 3 days post inoculation (dpi). On the other $7^{\text {th }}, 14^{\text {th }}$ and $21^{\text {st }}$ dpi, disease developments were scored according disease scale, susceptible and resistant cucurbits' genotypes were found. The pathogenicity test results revealed that VT18, Meltem F1, Poyraz F1 and 348 commercial cucumber varieties and Adana courgette, Kaledran cucumber 1 and Kaledran cucumber 2 landraces were the most resistant cucurbit genotypes. However, these pathogenicity tests have also resulted Kaledran melon 2 was the most susceptible landrace genotype against $P$. xanthii. In future studies, these resistant local, wild, and commercial genotypes will be able to use against destructive PM pathogens as sources of resistance.
\end{abstract}




\section{Giriş}

Cucurbitaceae familyası Amerika'dan Arjantin'e doğal bir yay1lım gösteren, 1lıman, tropikal ve subtropikal bölgelerde ekonomik olarak önemli olan kabakgilleri kapsamaktadır. Kabakgiller, dünya çapında yetiştiriciliği yapılan Cucurbitacea familyasına ait 119 cins ve 825 türden oluşmaktadır (Jeffrey 2005). Bu familyada yer alan Cucurbita cinsi içinde en fazla kültürü yapılan türler kabaklardır. 2018 yılında toplam kabak üretimi dünyada 2763932 tona ulaşmıştır (FAO 2018).

Kabakgil familyası bitkilerinde fungal, bakteriyel ve viral hastalık etmenleri son derece yıkıcı sonuçlara neden olmaktadır. Bunlar içerisinde fungal hastalıklarından olan küllemeler kabakgillerin oldukça yıkıcı hastalıklarından bir tanesidir (Robinson ve Decker-Walters 1997). Küllemeler, bitki hastalıkları içerisinde en yaygın olan grubu oluşturmaktadır. Külleme hastalıkları 650 monokotiledon ve 9000 dikotiledon türünde hastalık oluşturmaktadır (Shulze-Lefert ve Vogel 2000).

Cucurbitaceae ailesinde, külleme hastalığına iki ana tür sebep olmaktadır; Golovinomyces cichoracearum var. cichoracearum (D.C.) V.P. Heluta (synth Erysiphe cichoracearum D.C.) ve Podosphaera xanthii (Castagne) U. Braun ve N. Shishkoff (önceden Sphaeroteca fusca Blumer olarak bilinen synpha Sphaerotheca fuliginea) (Sitterly 1978; Miazzi ve ark. 2011).

Simptomlar beyazımsı, pudra benzeri yapılar şeklinde olup yaprak yüzeyi, yaprak sap1 ve gövde üzerinde, nadiren de meyvede külleme gelişimi gözlenmektedir (Zitter ve ark. 1996). Külleme hastalığından sorumlu olan iki farklı etmenden biri olan Podosphaera xanthii daha yaygındır (Braun 2001) ve diğer etmene göre daha saldırgandır. Bu hastalık etmeni sıcak ve nemli havalarda ortaya çıkmaktadır. Tarla şartlarında her iki etmene de rastlamak mümkündür. Golovinomyces cichoracearum hastalık etmeni serin bahar ve erken yaz aylarında ortaya çıktığından dolayı, daha düşük sıcaklık isteğine sahiptir (Blancard ve ark. 1989). Enfeksiyon için optimum sicaklık $20-27^{\circ} \mathrm{C}$ 'dir. Etmenin inkübasyon süresi 3-7 gündür. Etmenin yayılış gösterdiği alanlarda iki farklı tür, Podosphaera xanthii ve Golovinomyces cichoracearum tespit edilmiştir. Avrupa'da ilk olarak $P$. xanthii yayılış göstermiş iken daha sonra her iki türünde görüldüğü rapor edilmiştir (Epinat ve ark 1993; Kristkova ve ark. 2004; Sowell 1982; Cohen ve ark. 1993; McCreight ve ark. 1987). Tarla koşullarında enfeksiyonun gelişimi $38^{\circ} \mathrm{C}$ 'nin üzerinde durmaktadır.

\section{Materyal ve Metot}

\section{1. Örnek toplama ve sörvey çalışmaları}

Projede kullanılan yerel ve yabani kabakgiller toplanırken, Antalya ve Hatay arasında kalan bölgede üreticiler ile bizzat görüşülmüştür. Ticari hıyar çeşitleri VATAN Tohum A.Ş (Antalya, Türkiye) den temin edilmiştir. Temin edilen tüm tohumlar Akdeniz Üniversitesi Ziraat Fakültesi Bitki Koruma Bölümünde bulunan laboratuvarımıza getirilerek tek tek etiketlenmiştir. Etiketlenen tohumlar $+4 \mathrm{C}^{\mathrm{o}}$ 'deki buzdolabına yerleştirilmiş ve ihtiyaç duyuldukça buradan çıarılarak ekilmişlerdir. Çalışmada kullanılan yerli ve ticari tohumlar Çizelge 1'de verilmiştir.

$\mathrm{Bu}$ çalışmada hastalık içermeyen yerel, yabani ve ticari çeşitler kullanılmıştır. Çalışmalarda küllemeye hassas çeşit olarak Baccara hıyar çeşidi, Nunhems Tohumculuk A.Ş. (Serik, Antalya) den temin edilmiştir.
Çalışmada kullanılan külleme izolatı Nisan ayında Antalya ili Gazipaşa ilçesindeki kabakgil üretiminin yapıldığı seralardan temin edilmiştir. Küllemeler obligat patojen olduğu için yapay besi ortamına alınamamaktadır. Bu sebepten hastalık etmeninin kültüre alınabilmesi için, hassas Baccara (Nunhems: Bayer Group, Antalya) çeşidi kullanılmıştır (Şekil 1). Bitki yapraklarına külleme inokulasyondan önce 1/30 oranında seyreltilen Civa II klorür (Sigma, Almanya) ile yüzey sterilizasyonu kotiledon yapraklar üzerinde gerçekleştirilmiştir. Steril edilen kotiledon yaprakları üzerine bir kaş kılı yardımı ile steril külleme kolonisinden alınan tek bir spor bırakılmıştır. Böylelikle steril bitki üzerinde tek spordan üretilmiş saf külleme kolonisi üretilmiştir.

Kabakgillere steril olarak çoğaltılan sporlar samur firça yardımıyla rüzgar almayan bir alanda yeşil aksama yayılmıştır. İnokulasyonun birinci, ikinci ve üçüncü günlerinde diaminobenzidine ve trypan blue boyama yöntemleri ile hücre reaksiyonları ve konidia spor oluşumları incelenmiştir. İnokulasyondan sonra 7., 14. ve 21. günlerde bitkilerin sağlik durumlarına göre Adam ve Somerville (1996) 0-4 skalasına göre değerlendirilmiştir.

$\mathrm{Bu}$ skalaya göre 0 ; Hiç ya da çok sınırlı sporulasyon, fungus ve konidiospor çıplak gözle görülemez ve genellikle nekrotik lezyonlarla (HR) ile birlikte görülmektedir. 1; Düşük sporulasyon ile birlikte çok az miktarda külleme yaprak kenarında görülebilir. Bazen de HR gözlenebilir. 2; Orta derece ya da gecikmiş sporulasyon, yaprak yüzeyinin \%10-30 u külleme ile kaplanmıştır. HR görülmez. 3; Yoğun sporulasyon ile birlikte yaprak yüzeyinin $\% 30$ dan fazlası külleme ile kaplanmıştır. HR yoktur. 4; Neredeyse tüm yaprak yüzeyi külleme ile kaplanmıştır. Bitkiler aşırı hassaslık göstermektedir. $\mathrm{Bu}$ hastalık durum skalasına göre bitkilerin sağlık durum sonuçlarının ortalaması alınmıştır (Çizelge 1).

\subsection{Mikroskobik çalışmalar}

\subsubsection{Trypan blue boyama}

Fungal spor ve yapılarını görüntüleyebilmek için ThordalChristensen ve ark. (1997) yöntemine göre işlemler yapılmıştır. Bunun için $250 \mu \mathrm{g} \mathrm{ml}^{-1}$ trypan blue tartılarak laktik asit: gliserol: su (1 volüm (v): 1 v: 1 v) içeren solüsyonda çözülmüştür. Bitki yapraklardan klorofili temizleyebilmek için \%96 lık etanol kullanılmıştır. Cam bir zemin üzerine yerleştirilen Whatman kağıtları temizleme solüsyonuna daldırılmış ve temizleme solüsyonunun, Whatman kağıdı üzerinden yapraklara nüfuz etmesi sağlanmıştır. Bu kağıtlar üzerine yerleştirilen yaprak örneklerindeki klorofil, kimyasal solüsyon tarafından alınarak yapraklar saydam hale getirilmiştir. Klorofilden temizlenen yaprak örnekleri üzerine trypan blue damlatılarak 3 dakika (d) bekletildikten sonra faz kontrast 1 şık mikroskobunda incelenmiştir (Şekil 2).

\subsubsection{Diamino benzidin (DAB) boyama}

Bitki hücrelerinde oluşan süperoksit kararsız bileşiklerini in vivo ortamında görüntüleyebilmek için bir başka kararsız bileşik olan DAB metodu ile Thordal-Christensen ve ark. (1997) tarafından belirtildiği gibi boyama yapılmıştır. Trypan blue boyama ile fungus sporlarını ve fungal yapıları boyarken, bitki hücresi ve içeriği DAB ile boyandığı için penetre olan spor ile bitki hücresinde oluşan süperoksit oluşumları birlikte kombine edilerek ortaya konmuştur (Şekil 3). DAB solüsyonu hazırlanırken 0.1 gram 3',3' Diaminobenzidine tetrahydrochloride hydrate (Sigma-Aldrich, Almanya) tartılarak 
Çizelge 1. Külleme hastalık gelişimi skalasına göre kabakgillerin genotiplerin skorlanması.

Table 1. Scoring cucurbits's genotypes according to powdery mildew disease development scale.

\begin{tabular}{|c|c|c|c|c|}
\hline Adı & 7. Gün & 14. Gün & 21. Gün & Ortalaması \\
\hline VT 18 & 0.75 & 1 & 1.25 & 1 \\
\hline Meltem F1 & 0.66 & 0.66 & 0.66 & 0.66 \\
\hline Çamlıca Kavun & 2 & 0.66 & 1.33 & 1.33 \\
\hline Adana Hiyar & 1.66 & 1.5 & 2.5 & 1.86 \\
\hline Adana Karpuz & 2 & 3 & 3 & 2.66 \\
\hline Kaledran Karpuz & 1.66 & 2 & 2 & 1.88 \\
\hline Kaledran Kavun 2 & 2.5 & 3 & 4 & 3.16 \\
\hline K. Kara Karpuz & 2 & 0.75 & 1.5 & 1.41 \\
\hline Kaledran Karpuz 1 & 2.75 & 1.25 & 2 & 2 \\
\hline VT80 & 2.75 & 0.75 & 1.75 & 1.75 \\
\hline Çamlıca Bal Kabağı & 2.25 & 2.5 & 2.75 & 2.5 \\
\hline Ç.Göden Kavun & 2 & 1.25 & 1.5 & 1.58 \\
\hline Çamlıca Balkabağı 2 & 2 & 1.25 & 1.5 & 1.58 \\
\hline Şahin & 2 & 0.25 & 1.25 & 1.16 \\
\hline Bahar & 1.25 & 1.5 & 1.75 & 1.5 \\
\hline Adana Karpuz2 & 2.5 & 0.5 & 2 & 1.66 \\
\hline Kaledran Kavun & 1.75 & 1.75 & 2 & 1.83 \\
\hline Adana Kavun & 1.75 & 2.25 & 2.5 & 2.16 \\
\hline Ç. Göden Kabak & 2 & 0.5 & 1.5 & 1.33 \\
\hline Yerli Acur & 1.25 & 2 & 1.75 & 1.66 \\
\hline Ankara Kavun & 1.75 & 1.25 & 2 & 1.66 \\
\hline Eskişehir Kavun & 1.75 & 2 & 2.25 & 2 \\
\hline 303 & 0 & 1.5 & 1.5 & 1 \\
\hline Poyraz F1 & 0.75 & 0.75 & 1 & 0.83 \\
\hline Süs Kabağ1 & 1 & 1.5 & 2 & 1.5 \\
\hline Adana Kabak & 1 & 0.5 & 1 & 0.83 \\
\hline 348 & 0.75 & 0.5 & 1 & 0.75 \\
\hline K. Dilimli Kavun & 3 & 2.75 & 3 & 2.91 \\
\hline Kaledran hiyar1 & 0.75 & 0.5 & 0.75 & 0.66 \\
\hline Kaledran hiyar2 & 0.5 & 0.75 & 1 & 0.75 \\
\hline Çamlıca Hıyar & 3 & 2.25 & 3 & 2.75 \\
\hline Ç. Sakız Kabağı & 1.66 & 2 & 2.66 & 2.11 \\
\hline Adana Karpuz 3 & 1 & 1 & 3 & 1.66 \\
\hline 248 & 1.33 & 1.33 & 2 & 1.55 \\
\hline
\end{tabular}

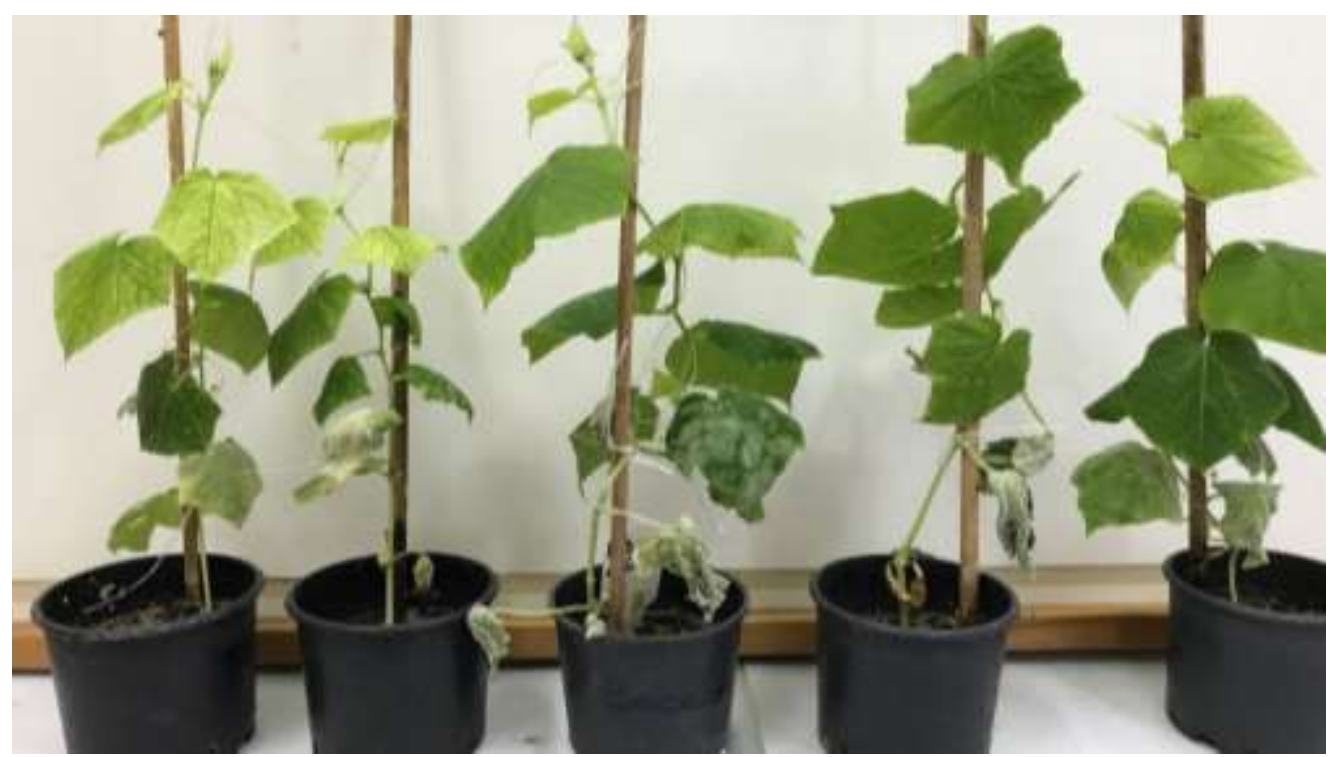

Şekil 1. Hassas hıyar çeşidi Baccara'da Podosphaera xanthii'nin gelişimi.

Figure 1. Development of Podosphaera xanthii on susceptible Baccara variety. 


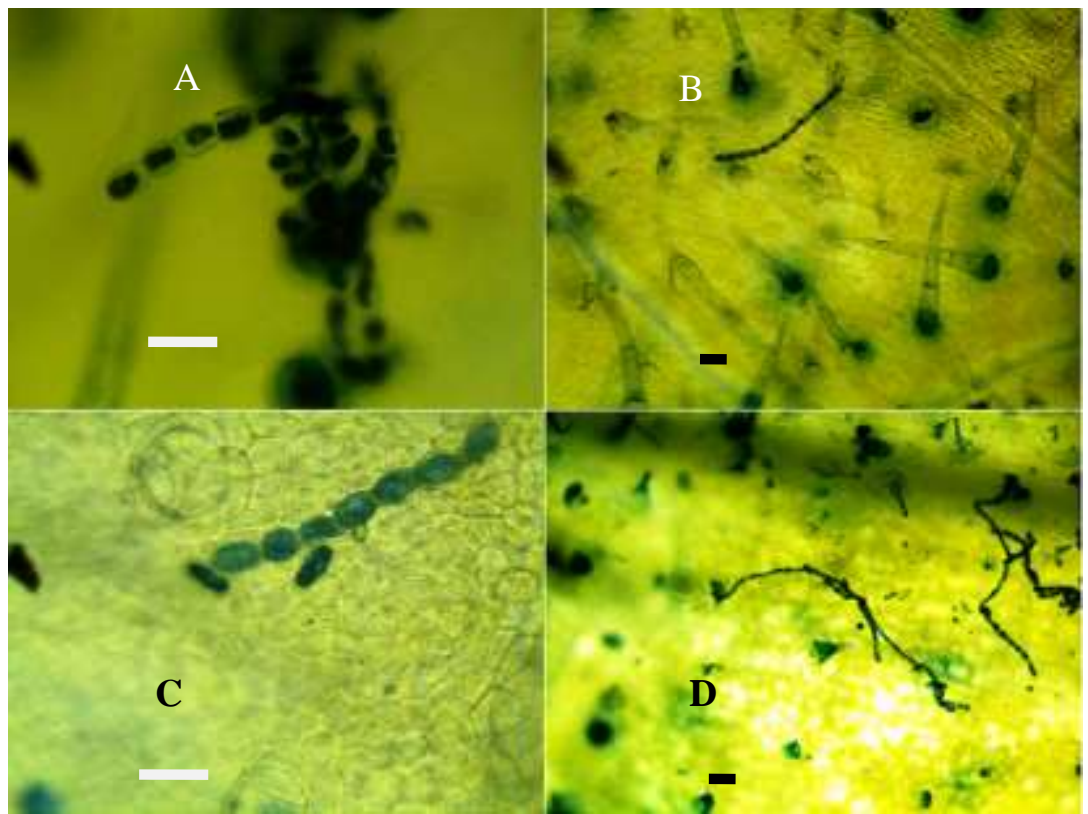

Şekil 2. Trypan blue ile boyanmış Podosphaera xanthii konidiosporları (Bar $20 \mu \mathrm{m})$.

Figure 2. Podosphaera xanthii conidiospores were stained with trypan blue (Bar $20 \mu \mathrm{m})$.

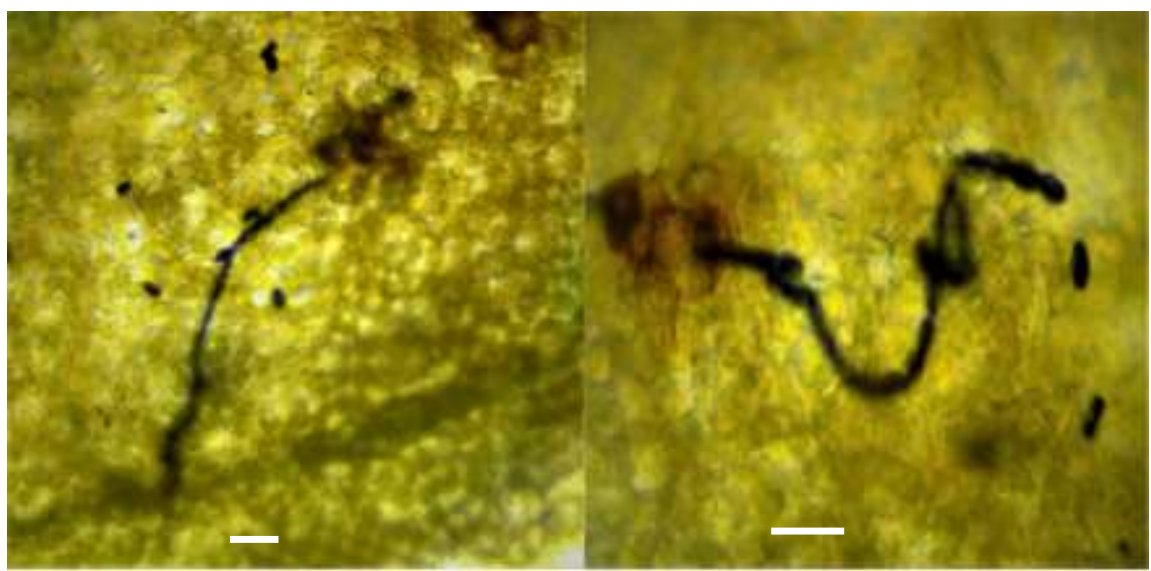

Şekil 3. DAB boyası ve trypan blue ile boyanmış süperoksit oluşturan bitki hücreleri ve üzerinde mavi renkli görülen Podosphaera xanthii konidiosporları. Her iki örnek VT 18 bitkisinde inokulasyondan sonra 3. günde çekilmiştir. Bar: $20 \mu \mathrm{m}$.

Figure 3. Superoxide produced plant cells associated with blue stained conidiospores of Podosphaera xanthii were dyed with DAB and trypan blue staining respectvely. Both samples were taken from VT18 plants at 3 days post inoculation. Bar: $20 \mu \mathrm{m}$.

$100 \mathrm{ml} \mathrm{ds} \mathrm{H}_{2} \mathrm{O}$ içerisinde çözülmüş ve pH: 3.0-3.5 olacak şekilde çözelti hazırlanmıştır (Thordal-Christensen ve ark. 1997).

\subsubsection{Floresan boyama}

3,3'- Dihexyloxacarbocynin iodide (DiOC6) \%96'lık saf etil alkol (Merck, Almanya) içinde $0.5 \mathrm{mg} \mathrm{ml}^{-1}$ olacak şekilde stok solüsyonu hazırlandi. Duckett ve Read (1991) tarafindan belirtildiği gibi hazırlanan bu stok $-20^{\circ} \mathrm{C}$ 'de saklanmıştır. Stok solüsyonu $\mathrm{dsH}_{2} \mathrm{O}$ içerinde 10 defa seyreltilerek hazırlanan çalışma konsantrasyonunda örnekler 1-2 dakika bekletilmiştir (Duckett ve Read 1991). Mikroskopta incelenmek üzere enfekteli yapraklardan preparat hazırland. Fungal hifler ve konidiosporlar parlak sarı renkte görünürken, örnek preparatlar DiOC6 çözeltisiyle maruz kalma süresine bağlı olarak, parlak yeşil ve sarı renklerde görülmektedir. Sağlıklı bitki hücreleri kloroplastların otofloresansı nedeniyle derin kırmızı bir renk sergilerken, hipersensitif hücre ölümü gösteren bitki hücrelerinin tamamen koyu siyah renkte 1şıma göstermedikleri görülmektedir (Şekil 4). Faz kontrast mikroskopa iliştirilmiş ultraviyole 1şık kaynağına bağlı B2A (450-490 nm excitation filtresi) ve $520 \mathrm{~nm}$ bariyer filtreler ile epiflorasan mikroskobi çalışmaları gerçekleştirilmiştir (Thordal-Christensen ve ark. 1997).

\subsection{Moleküler çalışmalar}

Kültüre alınan külleme etmeni hem klasik mikroskobi hem de moleküler olarak tanılanmıştır. Bunun için külleme etmenlerinin ribozom alt ünitelerindeki korunmuş DNA bilgileri ve bunlar arasında her bir türe göre değişkenlik gösteren Internal Transcribed Sequence (ITS) bölgeleri olan ITS1 ve ITS2 DNA siralamaların1 ortaya koyan ITS1 (5, TCCGTAGGSTGAACCTGCGG 3') /ITS4 (5' TCCTCCGCTTATTGATATGC 3') ve IT2 (5', 
CCTCCGCTTATTGATATGCTTAGG 3') /ITS5 (5' CTTGGTCATTTAGAGGA 3' primer setleri (White 1990) kullanılmışır. $\mathrm{Bu}$ primer kullanılarak polimeraz zincir reaksiyonunda (Polymerase Chain Reaction: PCR) hedef dizilimler çoğaltılmıştır.

Tek spordan Baccara hıyar çeşidi üzerinde çok miktarda üretilen külleme sporları bir samur firça yardımı ile $1.5 \mathrm{ml}$ 'lik tüpün içerisine toplanmıştır. Yaklaşık 0.4-0.5 ml kadar toplanan spor ve misellerden DNA izolasyonu modifiye edilen Doyle ve Doyle (1990)'e göre uygulanmıştır.

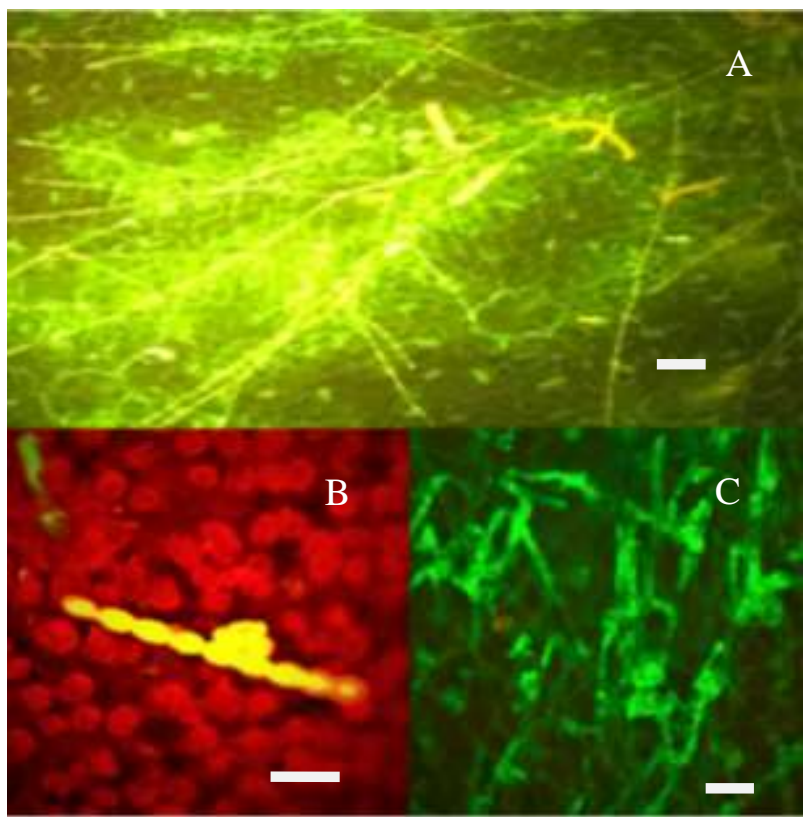

Şekil 4. 3,3'- Dihexyloxacarbocynin iodide (DiOC6) ile boyanmış çimlenmiş külleme sporlarının UV ışık altındaki görünümleri. Konidiosporlar sarı, yeşil ve bu renkler arası tonda (A ve C) görülürken sağlıklı klorofil içeren bitki hücreleri kırmızı renkte (B) görülmektedir. Bar: $20 \mu \mathrm{m}$.

Figure 4. Germinated powdery mildew spores were stained 3,3'Dihexyloxacarbocynin iodide (DiOC6) dye under in UV light microscope. Conidiospores seen in yellow, green and between these colors ( $A$ and $C$ ), while plant cells containing healthy chlorophyll, therefore, seen as red (B). Bar: $20 \mu \mathrm{m}$.

\section{Bulgular}

\subsection{Simtomatolojik bulgular}

Çalışmalarda Podosphaera xanthi olarak teşhis edilen külleme etmeninin Baccara hassas çeşidinde kitle üretimi sonucunda toplanan yerel, yabani ve kültür kabakgillerine inokulasyonu yapılmıştır. Çalıșmada toplanan 14 hıyar, 8 kavun, 4 karpuz, 3 su kabağı ve 1 sakız kabağından oluşan kabakgil bitkilerinin kotiledon ve gerçek yapraklarına konidiosporlar ile inokulasyonlar yapılmıştır. İnokulasyondan sonraki ilk 3 gün içerisinde hastalık etmenin gelişimini ve hücresel seviyede oluşan reaksiyonları gözlemleyebilmek için diaminobenzidine (DAB), trypan blue ve epiflurosan boya DIOC6 ile boyamalar yapılarak incelenmiştir. İnokulasyondan sonraki 7., 14. ve 21. günlerde hastalık gelişimi fenolojik olarak 0 ile 4 skalasına göre değerlendirilmiştir.

Çalışmada patojenisite testleri yerel ve yabani çeşitler arasında en dayanıklı bitkinin "Kaledran Hiyar 1" olarak adlandırılan hıyar çeşidi, en hassas çeşidin ise "Kaledran Kavun
2" olduğunu ortaya koymuştur. Genel olarak kavunların diğer kabakgillerden külleme etmenine daha hassas olduğu sonucu bulunmuştur. Karpuz ve kabakların ise kavuna göre nispeten küllemelere karşı daha yüksek toleransa sahip olduğu belirlenmiştir (Çizelge 2).

\subsection{Moleküler bulgular}

PCR işleminde Külleme sporlarının ribozomal DNA (rDNA) nin alt birimleri arasında olan Internal Transcried Spaces (ITS) bölgelerine bağlanan ITS1-ITS4 ve IT2-ITS5 primerleri kullanıldı.

Elde edilen PCR ürünleri \%1.5'lik agaroz jelde yürütüldükten sonra UV 1şı altında görüntülendi. ITS1-ITS4 primer seti 550 bp büyüklügünde, IT2-ITS5 primer seti 300 bp büyüklükte bir amplikon üreterek bantlar vermiştir (Şekil 5).

Primerler ile çoğaltılan ve içerisinde ribozomal DNA alt ünitesini (5.8 S) içeren ITS bölgelerinin büyükleri elde edilen PCR ürünleriyle aynı bulunmuştur. PCR ile çoğaltılan ITS1 ve ITS2 bölgelerindeki nükleik asit dizilimleri külleme türleri arasında farklılık gösterir iken bu ribozomal alt ünitelerdeki nükleik asit sıralamaları korunmuştur. Dolayısıyla PCR ile elde edilen bu bantlardaki nükleik asit sıralarını bulabilmek için elde elden PCR ürünleri ayn1 ITS1-ITS4 ve IT2-ITS5 primerleri ile birlikte DNA dizileme analizi yapılmıştır. DNA dizileme analiz sonuçları tüm canlıların genetik bilgilerinin depolandığı National Center for Biotechnology Information (NCBI) sistemi içerisindeki diğer organizmaların nükleik asit sıralarıyla karşılaştırılmıştır $\mathrm{Bu}$ nükleik asit sıralarının NCBI veri sistemindeki karşılaştırılmaları sonucunda izole edilen külleme fungusunun ITS DNA dizisi \%99 oranında Podosphaera xanthi olarak bulunmuştur.

Külleme izolatının ITS bölgelerini içeren DNA'sının NCBI sistemindeki mevcut olan diğer külleme DNA sıralamalarıyla karşılaştırılması (NCBI BLAST- Global Align) sonucunda projemizde izole edilen külleme etmeni ile NCBI sisteminde tanımlanmış olan külleme DNA (540 bp'lik bölgedeki nükleotid) sıralaması arasında sadece 3 nükleoitidin farklı olduğu bulunmuştur.

\section{Tartışma ve Sonuç}

Kabakgillerde çok büyük verim kayıplarına neden olan külleme hastalı etmenleri Podosphaera xanthii (=Sphaerotheca fuliginea Pollachi) ve Golovinomyces cichoracearum (=Erysiphe cichoracearum D.C) bu çalışmada ele alınmış, trypan blue boyama ve diaminobenzidin (DAB) boyama yöntemleri ile morfolojik olarak dayanıklılık testlemesi yapılmıştır.

Mikroskobik çalışmalar sonucu külleme etmeninin Podosphaera xanthii olduğu bulunmuştur. Bulunan külleme etmeninin NCBI da BLAST ile analizleriyle diğer organizmalar içerisinde \%99 oranında Podosphaera xanthii olduğunun bulunması sonuçlarımızın güvenirliliğini artırmıştır.

Testlemeler sonucunda ticari kabakgillerin yerel ve yabani türlere kıyasla daha dayanıklı oldukları ortaya konmuştur. Projede patojenisite testlerinin sonuçları incelendiğinde 9 ticari çeşidin yerel ve yabani kabakgillere kıyasla küllemelere karşı daha dayanıklı olduğu bulunmuştur. Bu dayanıklılığın nedeni tohum firmalarının 1slah programlarında küllemeye karşı dayanıklı genotiplere yer vermelerinden kaynakladığ düşünülmüştür. 
Bitki hastalıkları ile mücadelede ilk adım dayanıklı bitkilerin tercih edilmesidir. Dayanıklılık mekanizmasında süper oksitlerin oluşumu sonrasında hücre içerisinde patojenisite ile ilgili genlerin (Pathogenesis Related genes) oluşumu ve hipersensitif hücre ölümleri sonucunda bitki hücresi ölmekte dolayısıyla ölü bitki hücrelerinde beslenemeyen külleme etmeninin gelişimi de sonlanmaktadır (Xiao ve ark. 2001). Ancak bu dayanıklılık mekanizmaları model bitki olan Arabidopsis thaliana (Fare kulağı Teresi) üzerinde yapılan çalışmalar da külleme etmenlerine dayanıklılığın olduğunu ortaya koymuştur (Adam ve Somerville 1996; Xiao ve ark. 1997; Adam ve ark. 1999). Kabakgiller üzerinde yapılacak daha detaylı çalışmalar gelecekte külleme hastalıklarının kontrolünü sağlayan genlerin bulunmasını yardımcı olacaktır. Bu çalışma ile yerel, yabani ve bazı ticari kabakgillerdeki dayanıklılık durumları izole ettiğimiz $P$. xanthii patojenine karşı tanımlanmıştır. Böylece hastalık etmenine karşı kullanılabilecek tolerant ve hassas bitkiler belirlenmiştir (Çizelge 2). Ancak hıyar bitkilerinde külleme hastalık etmenlerine karşı dayanıklılık sağlayan genler tam anlamıyla aydınlatılmamıştır. Küllemeye karşı dayanıklılık hıyarda poligenik karakterde olup çevre şartlarından etkilenmektedir. $\mathrm{Bu}$ da dayanıklı bitki çeşitlerinin geliştirilmesini ve kullanılmasını kısıtlamaktadır.

Dayanıklılık genlerinin sağladığı dayanıklılığa alternatif olarak hassaslık genleri tanımlanmıştır. Çoğu patojen konukçunun içindeki uyumluluk faktörlerine ihtiyaç duymaktadır. Bu faktörler proteinlerdir ve patojenin konukçuyu tanımlaması için gereklidir. Başarılı bir enfeksiyonun temel gerekliliği budur. Özellikle sadece canlı hücre ile beslenebilen patojenlerde örneğin küllemeler, mildiyöler, bu ilişkiler büyük önem arz etmektedir. Bu sebeple bazı konukçu genlerinin ifade

Çizelge 2. Diaminobenzidine ve trypan blue boyama yöntemleri kullanılarak $P$. xanthii inokule edilmiş bitkilerde hücre reaksiyonları ve konidia sporların durumları. (D: Dayanıklı, H: Hassas).

Table 2. Podosphaera xanthii inoculated plants' cell reactions and conidiaspores situations within diaminobenzidine and trypan blue staining. (D: Resistant, H: Susceptible).

\begin{tabular}{|c|c|c|c|c|c|c|c|}
\hline \multirow[b]{2}{*}{ Adı } & \multicolumn{2}{|c|}{ 1. Gün } & \multicolumn{2}{|c|}{ 2. Gün } & \multicolumn{2}{|c|}{ 3. Gün } & \multirow{2}{*}{$\begin{array}{c}\text { Duyarlılık } \\
\text { Durumu }\end{array}$} \\
\hline & $\begin{array}{c}\text { Çimlenen } \\
\text { Spor }\end{array}$ & $\begin{array}{l}\text { Süperoksit } \\
\text { Oluşumu }\end{array}$ & $\begin{array}{c}\text { Çimlenen } \\
\text { Spor }\end{array}$ & $\begin{array}{c}\text { Süperoksit } \\
\text { Oluşumu }\end{array}$ & $\begin{array}{l}\text { Çimlenen } \\
\text { Spor }\end{array}$ & $\begin{array}{l}\text { Süperoksit } \\
\text { Oluşumu }\end{array}$ & \\
\hline VT 18 & Yok & Yok & Var & Var & Var & Var & $\mathrm{D}$ \\
\hline Meltem F1 & Var & Yok & Var & Yok & Var & Yok & $\mathrm{H}$ \\
\hline Çamlıca Kavun & Var & Yok & Var & Yok & Var & Yok & $\mathrm{H}$ \\
\hline Adana Hiyar & Var & Yok & Var & Yok & Var & Yok & $\mathrm{H}$ \\
\hline Adana Karpuz & Var & Yok & Var & Yok & Var & Yok & $\mathrm{H}$ \\
\hline Kaledran Karpuz & Var & Yok & Var & Yok & Var & Yok & $\mathrm{H}$ \\
\hline Kaledran Kavun 2 & Var & Yok & Var & Yok & Var & Yok & $\mathrm{H}$ \\
\hline K. Kara Karpuz & Var & Yok & Var & Yok & Var & Yok & $\mathrm{H}$ \\
\hline Kaledran Karpuz 1 & Var & Yok & Var & Yok & Var & Yok & $\mathrm{H}$ \\
\hline VT80 & Var & Yok & Var & Var & Var & Var & $\mathrm{D}$ \\
\hline Çamlıca Bal Kabağı & Var & Yok & Var & Yok & Var & Yok & $\mathrm{H}$ \\
\hline Ç.Göden Kavun & Var & Yok & Var & Yok & Var & Yok & $\mathrm{H}$ \\
\hline Çamlıca Balkabağı 2 & Var & Yok & Var & Yok & Var & Yok & $\mathrm{H}$ \\
\hline Şahin & Var & Yok & Var & Yok & Var & Yok & $\mathrm{H}$ \\
\hline Bahar & Var & Yok & Var & Yok & Var & Yok & $\mathrm{H}$ \\
\hline Adana Karpuz2 & Var & Yok & Var & Yok & Var & Yok & $\mathrm{H}$ \\
\hline Kaledran Kavun & Var & Yok & Var & Yok & Var & Yok & $\mathrm{H}$ \\
\hline Adana Kavun & Var & Yok & Var & Yok & Var & Yok & $\mathrm{H}$ \\
\hline Ç. Göden Kabak & Var & Yok & Var & Yok & Var & Yok & $\mathrm{H}$ \\
\hline Yerli Acur & Var & Yok & Var & Yok & Var & Yok & $\mathrm{H}$ \\
\hline Ankara Kavun & Var & Yok & Var & Yok & Var & Yok & $\mathrm{H}$ \\
\hline Eskişehir Kavun & Var & Yok & Var & Yok & Var & Yok & $\mathrm{H}$ \\
\hline 303 & Var & Yok & Var & Yok & Var & Yok & $\mathrm{H}$ \\
\hline Poyraz F1 & Var & Yok & Var & Yok & Var & Yok & $\mathrm{H}$ \\
\hline Süs Kabağ 1 & Var & Yok & Var & Yok & Var & Yok & $\mathrm{H}$ \\
\hline Adana Kabak & Var & Yok & Var & Yok & Var & Yok & $\mathrm{H}$ \\
\hline 348 & Var & Yok & Var & Yok & Var & Yok & $\mathrm{H}$ \\
\hline K. Dilimli Kavun & Var & Yok & Var & Yok & Var & Yok & $\mathrm{H}$ \\
\hline Kaledran hiyar1 & Var & Yok & Var & Yok & Var & Yok & $\mathrm{H}$ \\
\hline Kaledran hiyar2 & Var & Yok & Var & Yok & Var & Yok & $\mathrm{H}$ \\
\hline Çamlıca Hıyar & Var & Yok & Var & Yok & Var & Yok & $\mathrm{H}$ \\
\hline Ç. Sakız Kabağı & Var & Yok & Var & Yok & Var & Yok & $\mathrm{H}$ \\
\hline Adana Karpuz 3 & Var & Yok & Var & Yok & Var & Yok & $\mathrm{H}$ \\
\hline 248 & Var & Yok & Var & Yok & Var & Yok & $\mathrm{H}$ \\
\hline
\end{tabular}




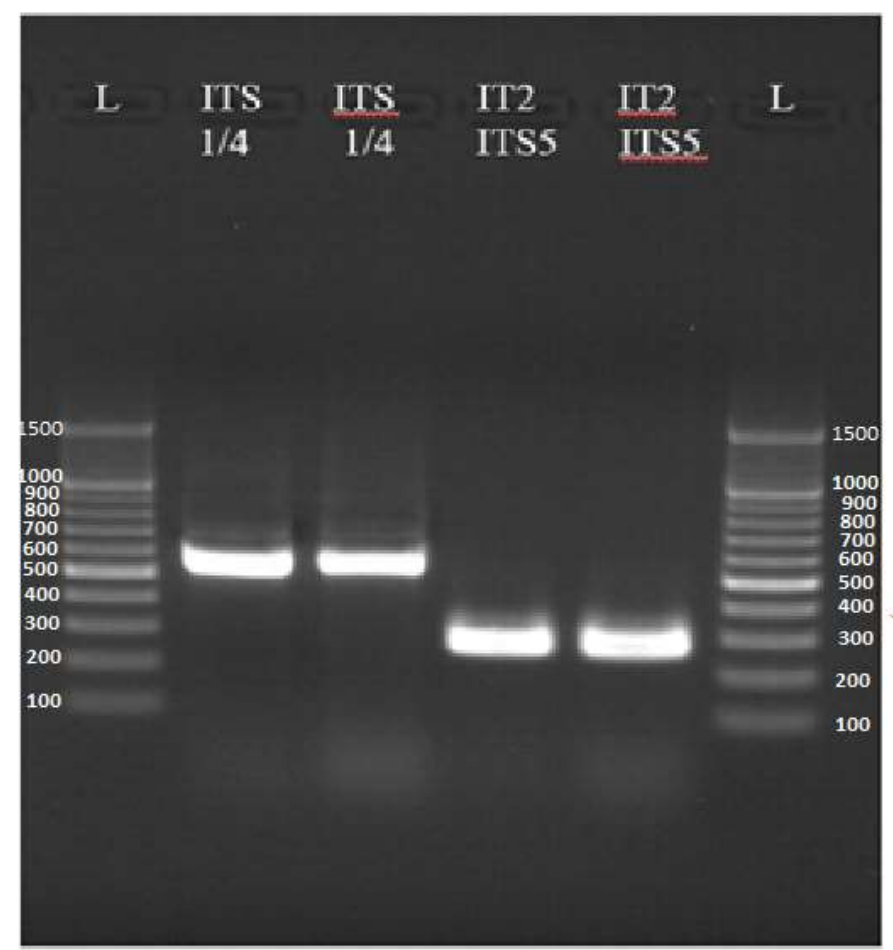

Şekil 5. Podosphaera xanthii'ye ait ITS bölgesinin ITS1/ITS4 ve ITS5/IT2 primerleri ile çoğaltılması ve jelde görüntülenmesi.

Figure 5. A gel image of Podosphaera xanthii's ITS regions produced with ITS1/ ITS4 and ITS5/ IT2 primer sets and imaging in gel.

edilmesi patojen için oldukça önemlidir. Bu genler hassaslık (S) genleri olarak tanımlanır ve konukçunun patojen tarafından tanınması, penetrasyonun gerçekleşmesine, dayanıklılığın negatif yönde düzenlenmesine, patojenin ihtiyaç duyduğu metabolitlerin sentezlenmesine neden olmaktadır (Van Schie Chris ve ark. 2014).

Hassaslık genlerinin fonksiyonunun kaybetmesine neden olan mutasyonlar geniş spektrumlu, uzun süreli ve çekinik karakterde dayanıklılık sağlayabilir. Buna en iyi örnek ise arpada bulunan mlo (mildew locus) genlerinin mutasyona uğratılması ile küllemeye karşı geniş spektrumlu dayanıklılığın oluşturulmasıdır. Hala daha birkaç izolat hariç bu dayanıklılığın devam etmesi, $S$ genleri mutasyonu sayesinde oluşturulan dayanıklılığın ne kadar uzun süreli olduğunun en önemli kanitıdır (Pavan ve ark. 2010).

İlk olarak arpada küllemeye karşı dayanıklılığı sağlayan mlo genlerinin keşfedilmesinden sonra bu genin diğer monokotiledon ve dikotiledon bitki türlerinde varlı̆̆ bulunmuştur. Hiyar bitkisinde 14 adet $M L O$ geni bulunmakta olup bunlardan üç tanesi (CsaMLO1, CsaMLO8 ve CsaMLO11) küllemeye karşı dayanıklılık ve hassaslık sağladığı ortaya konmuştur (Zhou ve ark. 2013). Moleküler olarak bu genler üzerinde yapılacak spesifik birer mutasyon ile hıyar bitkilerinde genetik olarak küllemelere dayanıklı bitkilerin üretimi mümkün olabilecektir. Yeni nesil genom düzenleme tekniklerinden birisi olan CRISPR/Cas9 (Clustered Regularly Interspaced Short Palindromic Repeats) biyoteknoloji yöntemi sayesinde hedef gen bölgesine spesifik nokta mutasyonları meydana getirilerek bu genlerin fonksiyonları engellenebilecektir. $\mathrm{Bu}$ teknik ile hiyar bitkilerindeki CsaMLO1, CsaMLO8, CsaMLO11 genleri üzerinde mutasyonlar meydana getirilerek küllemeye karşı uzun süreli, geniş spektrumlu dayanıklılık kazandırılabilecek ve genetiği değiştirilmemiş bitkiler elde edilebilecektir.

\section{Kaynaklar}

Adam L, Somerville SC (1996) Genetic characterization of five powdery mildew disease resistance loci in Arabidopsis thaliana. The Plant Journal 9: 341-356.

Adam L, Ellwood S, Wilson I, Saenz G, Xiao S, Oliver RP, Turner JG, Somerville S (1999) Comparison of Erysiphe cichoracearum and E. cruciferarum and a survey of 360 Arabidopsis thaliana accessions for resistance to these two powdery mildew pathogens. Molecular Plant-Microbe Interactions 12: 1031-1043.

Blancard D, Pitrat M, Jourdain F (1989) Etude de la sporulation de Pseudoperonospora cubensis (Berk, et Curt.) Rost, sur cotylédons de melon; application à la recherche de variétés résistantes. Phytopathologia Mediterranea 28: 169-175.

Braun U, Shishkoff N, Takamatsu S (2001) Phylogeny of Podosphaera sect. Sphaerotheca subsect Magnicellulatae (Sphaerotheca fuliginea auct. s.lat.) inferred from rDNA ITS sequences a taxonomic interpretation. Schlechtendalia 7: 45-52.

Cohen RA (1993) A leaf disk assay for detection of resistance of melons to Sphaerotheca fuliginea race 1. Phytopathology 54: 587-591.

Doyle JJ, Doyle JL (1990) Isolation of plant DNA from fresh tissue. Focus 12: 13-15.

Duckett JG, Read DJ (1991) The use of the fluorescent dye 3,3'dihexyloxacarbocyanin iodide for selective staining of ascomycete fungi associated with liverworth rhizoids and ericoid mycorrhizal roots. New Phytologist 118: 250-272.

Epinat C, Pitrat M, Bertrand F (1993) Genetic analysis of resistance of five melon lines to powdery mildews. Euphytica 65: 135-144.

FAO (2018) Food and Agricultural organization of the United Nations http://www.fao.org/statistics/en/. Accessed 08 June 2020.

Jeffrey C (2005) A new system of Cucurbitaceae. Botanicheskii Zhurnal 90: 332-335. 
Kristkova C, Leveda A, Sedlakova B (2004) Virulence of Czech cucurbit powdery mildew isolates on Cucumis melo genotypes MR1 and PI 124112. Scientia Horticulturae 99: 257-265.

McCreight JD, Pitrat M, Thomas CE, Kishaba AN, Bohn GW (1987) Powdery mildew resistance genes in muskmelon. Journal of the American Society for Horticultural Science 112: 156-160.

Miazzi M, Laguardia C, Faretra F (2011) Variation in Podosphaera xanthii on Cucurbits in Southern Italy. Journal of Phytopatology 159: 538-545.

Pavan S, Jacobsen, E, Visser RGF, Bai Y (2010) Loss of susceptibility as a novel breeding strategy for durable and broad-spectrum resistance. Molecular Breeding 25: 1-12.

Robinson RW, Decker-Walters DS (1997) Cucurbits. Wallingford: CAB International, New York.

Shulze-Lefert P, Vogel J (2000) Closing the ranks to attack by powdery mildew. Trends in Plant Science 5: 343-347.

Sitterly WR (1978) Powdery Mildews of Cucurbits. In; Spencer, DM, ed The Powdery Mildews, Academic Press, London.

Sowell GJr (1982) Population shift of Sphaerotheca fuliginea on musk melon. Journal of the American Society for Horticultural Science 112: $156-160$.

Thordal-Christensen H, Zhang H, Wei ZY, Collinge DB (1997) Subcellular localization of $\mathrm{H}_{2} \mathrm{O}_{2}$ in plants: $\mathrm{H}_{2} \mathrm{O}_{2}$ accumulation in papillae and hypersensitive response during the barley powdery mildew interaction. The Plant Journal 11: 1187-1194.

Van Schie C, Takken FL (2014) Susceptibility genes 101: How to be a good host. Annual Review of Phytopathology 52: 551-81.

White TJ, Bruns T, Lee S, Taylor JW (1990) Amplification and direct sequencing of fungal ribosomal RNA genes for phylogenetics. Pp. 315-322 In: PCR Protocols: A Guide to Methods and Applications, eds. Innis, M.A., D.H. Gelfand, J.J. Sninsky, and T.J. White. Academic Press, Inc., New York.

Xiao S, Ellwood S, Findlay K, Oliver RP, Turner JG (1997) Characterisation of three loci controlling resistance of Arabidopsis thaliana accession Ms-0 to two powdery mildew diseases. The Plant Journal 12: 757-768.

Xiao S, Ellwood S, Calis O, Patrick E, Li T, Coleman M, Turner JG (2001) Broad-spectrum mildew resistance in Arabidopsis thaliana mediated by $R P W 8$. Science 291: 118-120.

Zhou SJ, Jing Z, Shi JL (2013) Genome-wide identification, characterization, and expression analysis of the MLO gene family in Cucumis sativus. Genetics and Molecular Research 12: 65656578.

Zitter TA, Hopkins DL, Thomas CE (1996) Compendium of cucurbit diseases. APS Press, St. Paul. 